\title{
RISK AVERSION AND OVERCONFIDENCE IN GENDER PERSPECTIVE
}

\author{
Clara Bella Jessica Arijaya', Sautma Ronni Basana² \\ 1,2 Finance and Investment Program, Faculty of Business and Economics, Petra Christian University \\ Jl. Siwalankerto 121-131, Surabaya \\ E-mail: ${ }^{1 m 37416024 @ j o h n . p e t r a . a c . i d ; ~}{ }^{2}$ sautma@petra.ac.id
}

\begin{abstract}
This study analyzes the relationship between gender and risk aversion and overconfidence in making financial asset investment decisions for investors in Surabaya. The sample in this study amounted to 179 investors. Data were collected using a questionnaire. Methods of data analysis were performed using cross-tabulations and chi-square. This analysis shows that gender has a significant relationship with risk aversion and overconfidence in making financial asset investment decisions.
\end{abstract}

Keywords: Gender perspective, risk aversion, excessive self-confidence, financial behavior, investment decision making.

\section{INTRODUCTION}

Investment is a form of current investment commitments made in financial and non-financial instruments for several periods that are expected to benefit in the future (Bodie, Kane, \& Marcus, 2018). There are two types of investment, namely real asset investment and financial asset investment. Real asset investment is an investment of intangible assets, such as property (land and buildings), gold, and precious metals. In contrast, investment in financial support is an investment in intangible assets such as money market instruments, stocks, and bonds. These various types of investment in financial assets are traded in the Indonesian capital market.

In practice, making instrument investment decisions in the capital market is not only based on financial analysis such as fundamental analysis or technical analysis and techniques learned in books. According to Baker \& Ricciardi (2014), financial behavior can also be the basis for investment decisions, including the psychology that an investor can be involved in and can show the extent to which a person's psychological characteristics affect investment decisions (Kurniawan et al., 2020). According to Pompian (2012), there are two financial theories: traditional financial theory and behavioral finance theory. The traditional financial theory is a theory that rejects the idea that the psychology of the person himself can make good investment decisions. Behavioral finance theory (Behavioral Finance) is a theory that suggests that investors do not behave rationally all the time making investment decisions, causing emotional and cognitive bias. It is believed that there is a psychological effect that affects investors in making investment decisions (Widjaja \& Pertiwi, 2021).

According to De Bortoli, Da Costa, Gourlart, Campara (2019), the investment is chosen can show several types of investor attitudes towards risk whether he is a person who likes to take risks which can be called a risk seeker, or a risk avenger which can be called a risk averter. Another financial behavior that carries emotional biases is the behavior of overconfidence. Overconfidence is a condition where a person overestimates the knowledge, ability, and accuracy of the information they have or is too optimistic about the future and their ability to control (Ackert \& Deaves, 2009: 106). An investor is a party, either an individual or an institution originating from within the country or abroad, that carries out long-term and short-term investment activities (Nasarudin \& Surya, 2004). Differences in character between men and women have occurred in all aspects of life (Koerniawan \& Malelak, 2021), not only in the investment sector.

The research of Graham, Stendardi, Myers, \& Graham (2002), focuses on why women are more riskaverse and less confident in their decisions than men and suggest that it all happens because of differences in gender in information processing where women take more risks. And lower self-esteem, thus leading to women becoming wiser and more knowledgeable investors because they are more likely to ask questions, whereas men do so, taking all relevant investment factors into account. In contrast to 
other studies, in research Schubert, Brown, Gysler, and Branchinger (1999), found that women with controlled economic conditions generally do not make less risky investment decisions. From these two studies, it is clear that this is in contrast to previous studies. Judging from the history of existing research, the researcher finds that gender and investment behavior influence investment decision-making. Differences in gender has existed in various countries and have become the center of attention of researchers in almost every human civilization. So that makes the writer want to review it in research in Indonesia. This makes researchers want to know the relationship between gender and risk aversion and overconfidence in making investment decisions for investors' financial assets.

\section{LITERATURE REVIEW}

\section{Financial Behavior}

According to Thaler (1994) said that there are six assumptions of financial behavior, namely: 1) Humans always want to minimize expectations of regret (regret). This is in line with the opinion of Markowitz (1952), "Don't put your egg in one basket" means don't put all your assets in one kind of investment but divide your assets into several types of investments. It aims to minimize future regrets. 2) Financial behavior is a positive theory that describes something that has happened (ex-post). 3) Investors are loss averse. This is in line with the opinion of Kahnmena and Tversky (1979) that investors will be risk-averse when they profit but will be risk-takers when they lose. 4) Investors' predictions are often biased; this happens because investors do not process information correctly. 5) Financial behavior says investors always make investment decisions based on naive expectations; this shows that investors are trying to get a satisfactory return. 6) Financial behavior assumes that investors make investment decisions based on emotion, social, and psychology.

\section{Risk Averse}

There are two types of risk profiles, according to Gunawan (2015), namely aggressive and conservative. Aggressive investors are investors who tend to take risks (risk seekers). Risk avoidance can be influenced by financial knowledge and previous financial experience (Widjaja \& Pertiwi, 2021). Investors who risk returns should be considered risk-takers (Grable and Lytton, 1999). Meanwhile, conservative investors tend not to take risks or take the lowest risk with not high returns (risk averter).

\section{Overconfidence}

Overconfidence owned by investors reflects the conviction to get a return with an accurate knowledge of the capabilities (Bhandari \& Deaves, 2006). Excessive self-confidence can cause investors to bear greater risk than investors who are not overconfident in making investment decisions. Investor's overconfidence will underestimate risk and make investors overestimate their knowledge and underestimate the predictions made (Nofsinger, 2005).

\section{Prospect Theory}

Two leading scientists developed this theory from the United States, Daniel Kahneman, and Amos Tversky, in 1979. Not an approach about ordinary psychologists, but Prospect Theory is a combination of theory with economic theory psychologist. Prospect Theory states that economic actors are not always rational. In a sense, economic actors act not only looking at the rational and irrational side, but some aspects are more than just rational and irrational views. According to prospect theory, psychological accounting or mental accounting is a person who makes decisions to frame the choices offered and frame the results and consequences of those choices. This theory shows that people will make decisions by looking at the psychological state they have and looking at the long term for their choices. Another principle of the prospect theory is the value function, and namely, when a person loses 10 million of money, he will feel the value of the loss more than what he would feel when he earned a profit of 10 million. So, it can be concluded that the quality of sadness felt when a person loses 10 million is higher than the quality of joy when he gets 10 million. 


\section{Gender}

Gender is the difference between men and women biologically since a person is born (Hungu, 2007). In Ariadi's research (2015), it is also explained that gender is a biological, physiological, and characteristic difference that can distinguish men and women. Men certainly grow and develop with some distinctive values and independence with the hope of being assertive, straightforward, challenging, and not emotional. Likewise, women in their growth and development are expected to have a guiding, empathetic, compassionate, helpful, and gentle attitude.

\section{Investment Decision}

Tandelilin (2001), investment is a commitment to some funds or other resources made at this time to obtain an advantage in the future. The objective of investors to invest is to get a more decent life in the future and reduce the inflation rate. Two types of assets can be used as a means of investment: real assets and financial assets (Bodie et al., 2018). Real assets are investments in physical assets, for example, gold, property, land, machinery, buildings. At the same time, financial assets are investments by buying financial instruments, such as stocks, mutual funds, bonds, warrants, etc.

\section{Thinking Framework}

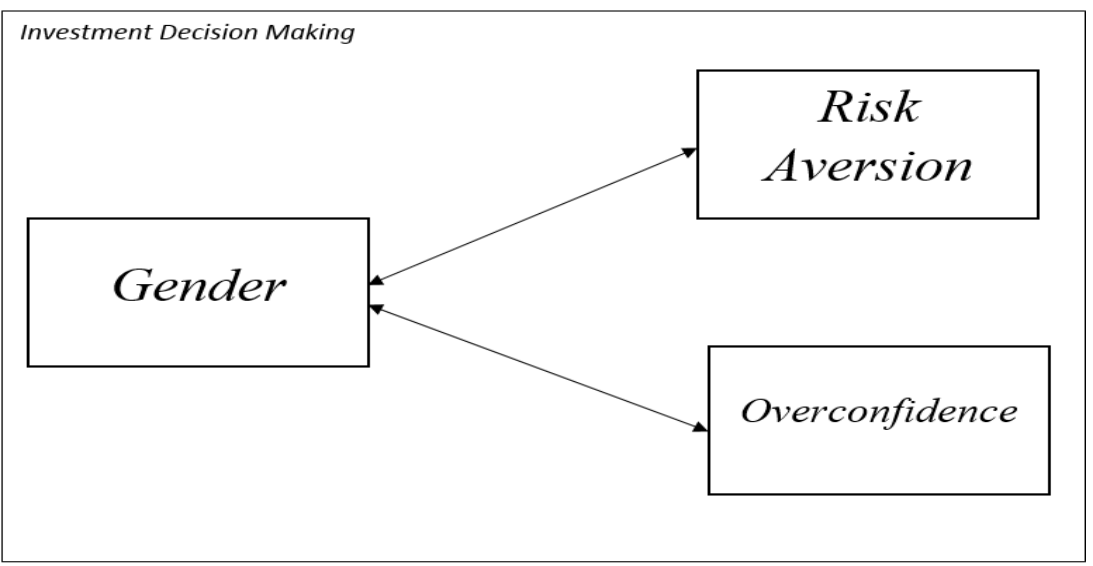

Figure1. Framework

\section{METHODOLOGY}

This type of research uses quantitative research with a deductive approach. According to Sugiyono (2010), a quantitative approach is a study whose results are presented in descriptions using numbers. Judging from the existing problems, researchers used two types of research, namely associative research. According to Sugiyono (2010), associative study with asymmetrical relationships aims to see the relationship between two or more variables that coincidentally appear. In this study, the population used in this study were all investors in Surabaya. Samples taken are investors who live in Surabaya and are in communities such as upaipro, Mirae assets and securities, victory, and currently investing activities. The sampling technique used purposive sampling. In this study, the sampling criteria are as follows: 1) The respondent is an investor who has one or more investments in financial assets. 2) Already an investor who has been investing for at least six months. 3) Respondents are more than 20 years old. In this study, the type of data used by researchers is primary data. Primary data was obtained through a survey by distributing questionnaires in hardcopy and softcopy forms of google form links to respondents according to the sample criteria. The questionnaire used in this study is a closed questionnaire, where respondents will answer questions and answer them by selecting a number of alternatives arranged in a multiple-choice form.

The method for data collection used in this research is quantitative methods. Quantitative methods will convert all answers into numbers. Data collection was carried out using questionnaires which were distributed in the form of hard and soft copies. The questionnaire form is in the form of multiple choices 
for variable risk aversion questions and a Likert scale for variable questions overconfidence. The Likert scale in this study is a Likert scale with a score of $1-5$, namely "Strongly Disagree" (STS), "Disagree" (TS), "Doubtful" (R), "Agree" (S), "Strongly Disagree" Agree"(SS).

Operational Variable Definition

1. Gender: biological, physiological, and characteristic differences that can differentiate men and women (Ariadi, 2015)

Empirical Indicators: Men (coded 0), Women (coded 1)

2. Risk aversion: Investors who have nature do not expect a high return rate because it does not dare to take a big risk. Investors at this level are classified as investors who invest safely and only consider risk-free investments (Bodie, Kane \& Marcus, 2018)

Empirical indicators:

a) The risk profile is seen from the description of themselves as risk-taking.

b) The risk profile is seen from taking alternatives when receiving unexpected funds.

c) The risk profile is seen from the mind when you hear the word risk.

d) The risk profile is seen from taking alternatives to betting by placing a number of funds into various options with different risks.

e) The risk profile is seen from taking alternatives when you feel lost.

e) The risk profile is seen from the risk options taken when obtaining an unexpected amount of funds. Source: Berggren \& Gonzalez (2010)

3. Overconfidence: A person tends to show overconfidence because of their knowledge and judgment (Bhandari \& Deaves, 2006)

Empirical indicators:

a) Confidence in the benefits obtained from the investment made.

b) Confidence in investment experience that is owned is better than other investors.

c) Confidence in knowledge (information, financial science) in the investment owned is better than other investors.

d) Confidence in investment selection.

e) Ignoring risks due to the capabilities they have.

Source: Anggirani, (2017)

Researchers collect the data through a questionnaire that has been distributed to respondents. The raw data that has been collected is then processed by chi-square assisted by SPSS software. The questionnaire was processed or encoded with numerical numbers to avoid confusion in data analysis. Conclusions will be presented in graphs or tables to make easier to read. The validity test is used to measure the validity of data from a questionnaire. A questionnaire item is declared valid if the value is sig. has a significant level of less than $5 \%$ (Ghozali, 2006). The test is a tool to measure the reliability of a questionnaire, an indicator of the construct variables. The reliability test will be carried out using the Cronbach's Alpha $(\alpha)$ statistical test provided that the variable under study is declared reliable if the Cronbach; s alpha ( $\alpha$ ) value is above 0.6 (Ghozali, 2006). According to Santoso (2008), the chi-square test is used to test the relationship or effect of two variables (row and column) and measure the relationship's strength between one variable and another.

$X^{2}=\sum \frac{(f o-f e) 2}{f e}$

Information:

$\mathrm{X}^{2}=$ khai-squared square

fo $=$ frequency of observation

$\mathrm{fe}=$ frequency of expectations

\section{ANALYSIS AND DISCUSSION}

The number of respondents involved was 188 investors, but 9 of the respondents did not meet the research criteria, namely not moderate investing in financial investment products, so that collected 179 respondents according to the research criteria. The researcher seeks to obtain demographic data on respondents classified into several criteria such as gender, age, education, occupation, income, 
investment experience, and investment owned. The researcher found that the results were dominated by male investors amounting to 96 (53.63\%), while female investors were 83 (46.36\%), with 179 investors participating in the survey.

The survey found that respondents in the 20-30 year age range dominated the research questionnaire, where 62 male investors (64.58\%) and 43 female investors $(51.81 \%)$ filled out the questionnaire. Meanwhile, at least in the age range of $50-60$ years, 2 male investors $(2.08 \%)$ and zero female investors $(0.00 \%)$ filled out the questionnaire. The survey results found that the last undergraduate education was dominating with 54 male investors (56.25\%) and 48 female investors (57.83\%). Another case with respondents who did not complete high school education amounted to 1 male investor (1.04\%) and two female investors $(2.08 \%)$.

Regarding the work status that the writer asked the respondent, the writer gave many options that the respondent could choose. From the survey results, it was found that men were dominant in work as private employees with 31 male investors (32.39\%). For female respondents, professional occupations such as lawyers, notaries, doctors, pilots, lecturers, and freelancers were the most male-dominated occupations, with 19 female investors (22.89\%). As a result, male respondents earn Rp. 3,000,000 - Rp. $5,500,000$ there are 30 male investors (31.25\%) who dominate. Meanwhile, in the income range of Rp. $5,500,001$ - Rp. 10,000,000, there were 26 female investors (31.33\%) dominated by female investors.

The result is dominated by respondents who have invested for 1 year to 3 years, with 38 male investors (21.23\%) and 36 female investors (20.11\%). When viewed from table 4.7, the investment experience of men is far more than that of women. This is based on the total male investors twice (2x) as many as female investors about five years ago. However, female investors have had significant growth. As of 6 months ago, the difference between male investors (29.17\%) and female investors $(25.30 \%)$ was not far apart. The result is dominated by male investors who carry out regular investment activities five days a week. Meanwhile, female investors are more dominant in investing in financial markets on a less regular basis, at least three days but less than five days a week.

When male investors and female investors are compared, it can be seen that there are differences in investment. Male investors (84\%) prefer the capital market as their investment compared to female investors (66\%), while female investors (42\%) prefer mutual funds as their investment compared to male investors (22\%). This shows that male investors prefer assets that can get a large return with a higher risk level than female investors.

In the first question, male investors describe themselves as more courageous risk-takers than female investors. When looking at the answer with the highest risk, we can see a significant difference between male and female investors. As much as $41.67 \%$ of male investors are high risk-takers, this is, of course, in stark contrast to female investors, who are only $3.61 \%$.

In the next question, the respondent's answer to the following question is dominated by the Indonesian Stock Market, both from male and female respondents. $54.17 \%$ male investors and $34.94 \%$ female investors chose to invest in the Indonesian stock market. However, this is inversely proportional to the minor level of risk, wherein bank savings accounts $22.89 \%$ of female investors chose this and only $9.38 \%$ of male investors. When viewed from the difference, we can conclude that male investors prefer high-risk alternatives to female investors. Likewise, with the next question, the result is that male investors tend to choose the word risk as an opportunity. On the other hand, female investors tend to choose the word chance as worried.

On the following question regarding case studies, $30 \%$ of male investors and $55 \%$ of female investors chose the low-risk option. However, male investors increased the next chance with a higher risk, while female investors decreased as the risk increased.

The next and final case study, dominated by male investors and female investors, is at medium risk. However, a significant difference occurred in the selection of high risk and low risk. Where male investors dominate at high risk and female investors dominate at low risk. According to the mean grouping of respondents' answers, male overconfidence investor in general in this study has overconfidence high (4.10). The dominant question of overconfidence is the Ov4 question $(4,47)$, which is about confidence in 
investing. According to the mean grouping of respondents' answers, the results of female overconfidence investor in general in this study have overconfidence low (2.93). The question that shows the smallest mean in the question overconfidence is of female investor in question Ov5 (2.40), which is about ignoring risk because of their ability.

In conducting the validity test, the results are valid for the variables for risk aversion and overconfidence in both male and female investors because the value of the correlation significance is less than 0.05 . The reliability test, the results were all reliable on the risk aversion and overconfidence variables, both male and female investors, because values are Cronbach's alpha all above 0.6. Test Chi-square on variable gender with the risk aversion of 0.00 , which is smaller than the chi-square significance value that has been set $(0.05)$. This shows that there is a significant relationship between gender and risk aversion. Risk aversion low; there are $26.5 \%$ (22 people) female investors and $82.3 \%$ (79 people) male investors from a total of $100 \%$ (179 people) respondents in this study in this study. Whereas at risk aversion high, there were 73.5 (61 people) female investors and $17.7 \%$ (17 people) male investors from a total of $100 \%$ (179 people) respondents in this study in this study.

The chi-square value on the variable gender with overconfidence is 0.000 , which is smaller than the chisquare significance value that has been set (0.05). This shows that there is a significant relationship between gender and overconfidence. At an overconfidence low, there were 63.9 (53 people) female investors and $12.5 \%$ (12 people) male investors from a total of $100 \%$ (179 people) respondents in this study. Whereas at risk aversion high, there were 36.1 (30 people) female investors and $87.5 \%$ (84 people) male investors from a total of $100 \%$ (179 people) respondents in this study in this study.

\section{Discussion}

In this study, researchers found that gender differences are a significant factor when making decisions, both in risk aversion and overconfidence. Barber and Odean (2001) argue that gender tends to influence individual choices.

Table 1. Decision Making

\begin{tabular}{lll}
\hline Variables & Decision Making & Information \\
\hline Gender with Risk aversion & Ho is rejected & Significantly \\
Gender with Overconfidence & Ho is rejected & Significant \\
\hline
\end{tabular}

Researchers divide the research object into two samples, namely male investors and female investors. Gonzach (2001) said that risk is an important feature that must be considered when making an investment decision. The results of the answers of male investors show that male investors show a greater tendency to take risks than women. This can be seen from the first question regarding risk aversion, where female investors dominate the picture of themselves as risk-averse, with the figure reaching $30.12 \%$. In another case with male investors who describe themselves as risk-averse, only $3.13 \%$. The overall results of the answers to the study case questions posed by the researcher illustrate those men tend to ignore the lowest-risk alternatives and strive towards higher-risk options with considerations of higher returns. The opposite trend is found by female investors who prefer lower-risk alternatives.

However, when viewed from the fourth question (RA4) table 4.13 that investors apply a certainty effect, investors will give greater weight to a condition that offers more specific results than conditions that provide probability alone. In table 4.13 , there are more minor results from the male (24\%) and female (7\%) investors when choosing conditions that have a greater probability of not getting anything. While the condition with a more negligible possibility of getting nothing, the results are greater, namely male investors $46 \%$ and female investors $37 \%$.

Women can be categorized as individuals who have a higher risk aversion than men. Age is also a contributing factor for someone to avoid risk or not. Young male investors (20-30 years) have profile risk aversion a low. This is consistent with the results researched by Evans (2004), a younger investor (under 30 years) has a more risk-averse profile, while an older investor (over 30 years) has a risk-averse profile. Young female investors (20-30 years) have a high-profile risk aversion. This is consistent with research 
by Saputra (2013), which states that the older the investor is, the investor's risk profile will tend to prefer risk, which means that younger investors have a risk profile that tends to be risk averse.

Overconfidence is a condition in which an investor feels capable, overconfident, and has optimistic thoughts in predicting the future (Bhandari and Deaves, 2006). The overconfidence owned by male investors is greater than that of female investors. It is shown in every answer given. From the results of the solutions to the variable for overconfidence female investors, on average, the three questions of which have results overconfidence low. For example, in the 3rd statement, investors' confidence in information and financial science is better than other investors. The result was that dominant female investors answered disagreement with the statement. This is in line with the opinion of Graham et al. (2002), women with overconfidence low in investment will tend to consider all available information and ask many questions to make decisions. The study results found that women had a level of lower overconfidence than men. When viewed from the investment intensity factor, men are more regular in investing than women. This is in accordance with Barber and Odean (2001), who state that the more often investors make investments, the confidence of these investors will increase. There is also research from Lewellen, Lease \& Schlarbaum (1977) that men spend more time and money analyzing investments, make more transactions, and rely less on brokers than women. This shows that men have a higher level of self-confidence than women in terms of investing.

\section{CONCLUSIONS AND RECOMMENDATIONS}

\section{Conclusions}

Based results of the analysis and discussion that has been carried out, the conclusions of this study are:

1. Gender variable has a significant relationship with risk aversion in investment decision making. Women are more likely to be risk aversion in making investment decisions than men.

2. Gender variable has a significant relationship with overconfidence in investment decision-making. Men are more likely to be overconfident in making investment decisions than women.

\section{Suggestions}

Based on the results of the study, the recomendations of this study are:

1. This study uses the object of research by investors on financial assets. It is suggested for further research to add the thing of investor research to real assets because investors in real assets such as property are also growing rapidly.

2. Researchers who wish to continue this research are advised to select objects based on other demographic factors such as income, age, occupation as the main focus of the object, considering that this research focuses mainly on objects grouped by gender.

\section{REFERENCES}

Ackert, LF \& Deaves, R. (2010). Behavioral Finance. Psychology, Decision-Making, and Markets. United State: Cengage Learning.

Ariadi, 2015. Analysis of The Relationship Between Financial Literacy and Demography with Investment, Saving and Consumption. Journal of Finsta, Volume 3 No. 1. Pg. 7-12.

Baker, H., \& Ricciardi, V. (2014). Investor Behavior: The Psychology of Financial Planning and Investing (Kolb Series). United State: John Wiley \& Sons, Inc.

Barber B. and Odean, T. (2001), "Boys Will Be Boys: Gender Overconfidence and Common Stock Investment ", Working Paper, University of California at Davis.

Bhandari, G., \& Deaves, R. (2006). The Demographics of Overconfidence. Journal of Behavioral Finance, 7(1), 511. doi: 10.1207/s15427579jpfm0701_2

Bodie, Z., Kane, A., \& Markus, A. (2018). Investment. Eleventh Edition. North America: McGraw-Hill.

De Bortoli D, da Costa N Jr, Goulart M, Campara J (2019). Personality Traits and Investor Profile Analysis: A Behavioral Finance Study. Romania: The Bucharest University of Economic Studies.

Grable, J., Lytton, R H. (1999). "Financial Risk Tolerance Revisited: The Development of A Risk Assessment Instrument." Financial Services Review 8 (1999) 163-181.

Graham, J., Stendardi, E., Myers, J., \& Graham, M. (2002). "Gender Differences in Investment Strategies: An Information Processing Perspective." International Journal of Bank Marketing, 20(1), 17-26. doi: 10.1108/ 02652320210415953 
Gunawan, MF (2015). Pengaruh Risk Tolerance dan Personality Tratis Terhadap Pemilihan Portofolio Investor di Surabaya. Universitas Kristen Petra. Surabaya.

Hungu. (2007). Demografi Kesehatan Indonesia. Jakarta: Penebit Grasindo.

Kahneman, D., dan Tversky, A. 1972. Subjective probability: A Judgment of Representativeness. Cognitive Psychology, 3, 430-454.

Koerniawan, S. A., and Malelak, M. I. (2021). The Influence of Female Director on The Probability of Companies Experiencing Financial Distress. International Journal of Financial and Investment Studies (IJFIS), 1(2), 101108. Retrieved from https://ojs.petra.ac.id/ijis/index.php/ijfis/article/view/59.

Kurniawan, J. Y., Malelak, M. I., and Astuti, D. (2020). Pengaruh Attitude, Subjective Norm, Past Behavior, dan Perceived Control Terhadap Budgeting Intention Mahasiswa di Surabaya. International Journal of Financial and Investment Studies (IJFIS), 1(1), 21-29. https://doi.org/10.9744/ijfis.1.1.21-29.

Lemenshow, S., Hosmer., Klar, J., \& Lwanga, S. (1990). Adequacy of Sample Size in Health Studies. England: John Wiley \& Sons Ltd.

Lewellen, W., Lease, R., \& Schlarbaum, G. (1977). Patterns of Investment Strategy and Behavior Among Individual Investors. The Journal of Business. 50. 296-333. 10.1086/295947.

Markowitz, HM (1952) "Portfolio Selection" The Journal of Finance: XXI pages 77-91

Nasarudin, MI, \& Surya, I. (2004). Aspek Hukum Pasar Modal Indonesia. Jakarta: Prenada Media.

Nofsinger, John R. (2005). Psychologi of Investing. Second Edition. New Jersey. Precentice-Hall inc.

Pompian, Michael M. (2012); Behavioral Finance and Investor Types: Managing Behavior to Make Better Investment Decisions; John Wiley \& Sons.

Santosa, S. (2015) Menguasai SPSS 22. Jakarta: PT. Elex Media Komputindo.

Saputra, Herwono Indra. (2013). Jenis Investasi Berdasarkan Profil Risiko. FINESTA Vol. 1, No. 2, (2013) 47-52

Schubert, R., Brown, M., Gysler, M., \& Brachinger, H. (1999). Financial Decision-Making: Are Women Really More Risk Averse? American Economic Review, 89(2), 381-385.

Sugiyono. (2010). Metode Penelitian Kuantitatif, Kualitatif, dan R \& D. Bandung: Alfabeta.

Tandelilin, E. 2001. Portofolio dan Investasi. Edisi Pertama. Yogyakarta: Kanisius.

Thaler, RH 1994. Psychology dan Saving Policies. American Economic Review, Vol. 84, No. 2, pp. 186-192.

Widjaja, R. and Pertiwi, D. (2021). The Influence of Emotional Factors, Materialism, Risk Perception, and Financial Literacy on The Tendency of Debt of Millennial Generation in Surabaya. International Journal of Financial and Investment Studies (IJFIS), 1(2), 85-93. Retrieved from https://ojs.petra.ac.id/ijfis/index.php/ifis/article/view/57 